Conring, C. M., K. Brautigam, B. A. Grisham, D. P. Collins, and W. C. Conway. 2019. Identifying the migratory strategy of the Lower Colorado River Valley population of Greater Sandhill Cranes. Avian Conservation and Ecology 14(1):11. https://doi.org/10.5751/ACE-01352-140111

Copyright (C) 2019 by the author(s). Published here under license by the Resilience Alliance.

Research Paper

\title{
Identifying the migratory strategy of the Lower Colorado River Valley population of Greater Sandhill Cranes
}

\author{
Courtenay M. Conring ${ }^{1,2}$, Kathryn Brautigam ${ }^{1}$, Blake A. Grisham ${ }^{1}$, Daniel P. Collins ${ }^{3}$ and Warren C. Conway ${ }^{1}$ \\ ${ }^{1}$ Department of Natural Resources Management, Texas Tech University, ${ }^{2}$ Alabama Department of Conservation and Natural \\ Resources, ${ }^{3}$ U.S. Fish and Wildlife Service, Southwest Region
}

\begin{abstract}
Across North America, Sandhill Cranes (Antigone canadensis) use an array of migratory strategies, ranging from "jumping," or taking 1 or 2 flights from wintering grounds to a staging area, then on to the breeding grounds, to "hopping," or taking shorter flights among multiple (>3) staging areas between termini. We captured 16 adult and 2 juvenile Greater Sandhill Cranes (Antigone canadensis tabida) from the Lower Colorado River Valley population (LCRVP) and fitted them with platform transmitter terminals (PTTs) for GPS satellite telemetry. We used recorded locations and Brownian bridge movement models (BBMMs) to identify migration corridors and areas of migratory use (AMUs) during spring and fall migration (2014-2016). Eighty-nine percent of our sample $(\mathrm{n}=16)$ of LCRVP Sandhill Cranes with PTTs flew direct paths between summer and winter termini. Starting in the Great Basin and moving into the Mojave Desert and then into the Sonoran Desert, the LCRVP aligned its migration with drainages, rivers, and reservoirs. Within those direct paths, we identified 18 unique and discrete AMUs along an $\sim 1000-\mathrm{km}$ corridor and 3 within minor corridors taken by the other 2 cranes. We defined AMU as an area within a crane's 75\% BBMM migration confidence contour where the crane had 2 or more subsequent time stamps (could be $\geq 3$ hours) and did not travel $>40 \mathrm{~km}$ from the first time stamp. The average migration duration was 23 days (spring, $\mathrm{n}$ $=3$; fall, $\mathrm{n}=2$; cranes, $\mathrm{n}=53$ ). The fact that many individuals stopped several times after relatively short flights during both migration seasons suggests that the LCRVP generally uses a "hop" migration strategy. The use, often frequent and consecutive, of the 21 AMUs in this research reveals the potential importance of these migration areas to the LCRVP for its social, behavioral, and energetic requirements during migration.
\end{abstract}

\section{Détermination de la stratégie de migration adoptée par les Grandes Grues du Canada appartenant à la population de la vallée du Colorado inférieur}

RÉSUMÉ. En Amérique du Nord, la Grue du Canada (Antigone canadensis) a recourt à diverses stratégies de migration, allant des « grands sauts », c'est-à-dire d'effectuer un ou deux vols de l'aire d'hivernage à une halte printanière pour ensuite se rendre à l'aire de nidification, aux « petits bonds », soit d'entreprendre des vols plus courts entre plusieurs haltes ( $>3)$ jusqu'à la destination finale. Nous avons capturé 16 adultes et 2 jeunes Grandes Grues du Canada (Antigone canadensis tabida) appartenant à la population de la vallée du Colorado inférieur (PVCI) et les avons munis d'une balise radio avec télémétrie satellitaire GPS. Nous avons utilisé les positions enregistrées et des modèles de déplacement fondés sur le pont brownien (MDPB) pour déterminer les corridors de migration et les secteurs utilisés en migration (SUM) printanière et automnale (2014-2016). Quatre-vingt-neuf pourcent de notre échantillon $(\mathrm{n}=16)$ de grues équipées de balise ont parcouru des trajets directs de leur aire de nidification à leur aire d'hivernage. Au départ du Grand Bassin, les grues de la PVCI ont transité par le désert de Mojave, puis le désert du Sonora, suivant les bassins hydrographiques, les rivières et les réservoirs. Parmi ces trajets directs, nous avons repéré 18 SUM uniques et distincts le long d'un corridor d' $1000 \mathrm{~km}$ et 3 dans des corridors secondaires aussi utilisés par les deux autres grues. Nous avons défini un SUM comme étant l'aire contenue à l'intérieur du couloir migratoire d'une grue délimitée par la ligne de contour obtenue avec le MDPB à un niveau de confiance de $75 \%$ et où au moins deux positions subséquentes ou plus (pouvant être de $\geq 3$ heures) ont été enregistrées, montrant un déplacement de $>40 \mathrm{~km}$ depuis la première position. La durée moyenne de migration était de 23 jours (printemps, $n=3$; automne, $n=2$; grues, $n=53$ ). Le fait que de nombreux individus soient arrêtés plusieurs fois à la suite de vols relativement courts durant les deux migrations saisonnières semble indiquer que les grues appartenant à la PVCI utilisent habituellement la stratégie de migration par «petits bonds ». L'utilisation souvent fréquente et consécutive des 21 SUM identifiés dans le cadre de cette étude révèle l'importance possible de ces secteurs pour combler les besoins sociaux, comportementaux et énergétiques de la PVCI au cours des migrations.

Key Words: Lower Colorado River Valley; migration; migration strategy; migratory corridor; Sandhill Cranes

\section{INTRODUCTION}

Migration is a behavioral adaptation for exploiting temporal peaks of resource abundance and avoiding temporal resource depression (Alerstam et al. 2003, Winkler et al. 2014). Resource availability is geographic and temporally variable during migration, and as such, migratory birds typically adjust their migration strategy with the associated changes in resource abundance. Although multiple migration strategies exist, for discussion purposes, a simplified

Address of Correspondent: Blake A Grisham, 15th and Detroit, Texas Tech University, Box 42125, Lubbock, TX 79409, United States, Blake. Grisham@ttu.edu 
categorization is provided by Piersma (1987) who defined three migration strategies: hop, skip, and jump. Although the traditional definitions have been altered and expanded given new data, the original definitions are as follows: hop is defined as traveling short distances between sequential sites and accumulating small amounts of extra fuel (food) when stopped; skip is defined as traveling longer distances between sequential sites and accumulating medium amounts of extra fuel; and jump is defined as traveling long distances (thousands of kilometers) between sequential sites and accumulating large amounts of extra fuel (Piersma 1987, Warnock 2010). Warnock (2010) suggested that duration of stay at stopover or staging sites, predictability of food resources, and foreseen obstacles are all correlated with these strategies. These strategies can be depicted as concepts along a continuum with a single migratory flight between breeding and wintering termini at one extreme, and multiple short flights between multiple suitable stopover locations at the other extreme of the strategy spectrum. Hopping and skipping result in short (hours or days) stays between short flights, whereas jumping usually results in longer (weeks or months) stays between longer flights at staging areas where food sources are reliable and abundant (Warnock 2010). These migration strategies are associated with different stopover behaviors and typically are correlated with total migration distance and amount of extra fuel intake at stopovers. Abiotic factors, such as stochastic weather events or environmental conditions, e.g., storm and flood, can potentially affect time spent at a stopover.

Sandhill Cranes (Antigone canadensis; also cranes) migrate in multiage groups, typically composed of multiple family groups ( 2 adults and 1 or 2 juveniles; Holmgren et al. 1993, Restani 2000, Galván 2005) and subadult groups (2-3 years old). The family groups stay together during the colt's first fall migration and winter, minimizing risks associated with inexperienced migration of juveniles (hatch year; Tacha 1988). Sandhill Cranes, like other migratory game birds, are categorized into management units, or populations, based on their distribution, which includes their winter, summer, and migration ranges. Many aspects of migration, e.g., distance, duration, phenology, and so forth, vary widely among crane subspecies and migratory populations. For example, cranes from the midcontinent population (MCP), composed of both Antigone canadensis tabida (Greater Sandhill Crane, also greaters) and Antigone canadensis canadensis (Lesser Sandhill Crane, also lessers), are long-distance migrants that exhibit a jump strategy (Warnock 2010) with major staging areas along the Platte River in Nebraska and in Saskatchewan (Lovvorn and Kirkpatrick 1981, Krapu et al. 1984, Fronczak 2014, Krapu et al. 2014). The MCP breeds as far north as eastern Siberia and winters as far south as Mexico, with known migrations ranging from 2000 to more than $7000 \mathrm{~km}$ between termini, taking at least 2 months to complete in most cases (Krapu et al. 2014). Another relatively long-distance migratory population consisting of both lessers and greaters is the Pacific coast population. However, cranes from the Pacific coast population take only about 27 days to migrate $3600 \mathrm{~km}$ between breeding and wintering grounds (Petrula and Rothe 2005), use either a hop or skip migratory strategy, and make many stops during both spring and fall migrations (Ivey et al. 2005). These 2 populations alone demonstrate the migratory heterogeneity found in the species, and research is slowly revealing where the remaining populations' strategies fit along the spectrum.
Research aimed at gaining a basic understanding of the migratory ecology of the 3 intermountain populations (Central Valley, Lower Colorado River Valley, and Rocky Mountain) is ongoing. Specifically, the Lower Colorado River Valley population (LCRVP), one of the least studied of all the migratory populations, has experienced increased interest in determining the migratory strategy of the population in recent years (Collins et al. 2016). Compared with the midcontinent and Pacific populations, the LCRVP is far less abundant with a 3-year average of 2509 cranes (Dubvosky 2018); cranes from the LCRVP have shorter distances between seasonal termini to traverse and are known to take less time to complete migration (Collins et al. 2016). Given the long-distance flights of midcontinental cranes ( 700-1000 km; Krapu et al. 2014; K. J. Brautigam, Texas Tech University, unpublished data) completed in $\sim 1$ day, effectively nullifying the need for fuel during migration, we expect a crane from the LCRVP to have the phenotypic requirements, both genetic and environmental, to complete migration between seasonal termini of relatively short distances $(500-1000 \mathrm{~km})$ with little to no stopping. However, although not explicitly stated in the literature, based on stopover and staging research (D. Collins, personal observation), it appears that cranes from the LCRVP generally exhibit the "hop" migration strategy (Piersma 1987, Warnock 2010).

Bird populations that use the hop migration strategy tend to travel comparatively short total migration distances over land; tend to have relatively continuous, predictable, and reliable food resources available along their migratory corridor; and tend to not travel over large geographic barriers (Warnock 2010). The LCRVP summer range includes northeastern Nevada and parts of Idaho and Utah; the winter range includes southwestern Arizona and southeastern California; and the ecosystem between termini is primarily the Great Basin, but also portions of the Mojave Desert and the Sonoran Desert. The LCRVP occupies the spatial gap between the other two western crane populations, the Rocky Mountain and Central Valley populations (Fig. 1). The three populations intermix (Collins et al. 2016) but are currently managed and identified as separate entities. Causal mechanisms that facilitate population mixing, i.e., overlap in breeding distribution, intermingling during migration, and so forth, have been observed, and the spatial arrangement of termini and food resources anecdotally suggest intermixing may occur via hopping within their combined distributions. Understanding the extent of the migration corridors, stops, and movement patterns for the LCRVP is imperative for habitat management but also provides a unique opportunity to assess if migration is one causal mechanism responsible for population intermixing in the Intermountain West. Our objectives were to identify the migration strategies for cranes from the LCRVP and locate areas of migratory use (AMUs) along the migration corridor.

\section{METHODS}

\section{Study areas}

\section{Geographic range}

Nearly the entire geographic range and migration corridor of the LCRVP lies within the Great Basin, the largest contiguous watershed in North America. This vast watershed is $\sim 542,000 \mathrm{~km}^{2}$ and extends across most of Nevada, the western half of Utah, and portions of California, Oregon, Idaho, and Wyoming. The 
ecosystems found there include sagebrush, warm and cold deserts, salt flats, riparian and playa wetlands, montane shrublands and timberlands, pinyon-juniper communities, and many other elevation- and slope-specific ecosystems found at elevations between $-86 \mathrm{~m}$ (Death Valley) and $4421 \mathrm{~m}$ (Mt. Whitney). Sites were chosen by collaborators and agency biologists because of access to fields on and near federal refuges and crane presence during weeks leading up to capture in January 2014.

Fig. 1. Sandhill Crane (Antigone canadensis) population map, with the Lower Colorado River Valley population distribution in upper right inset.

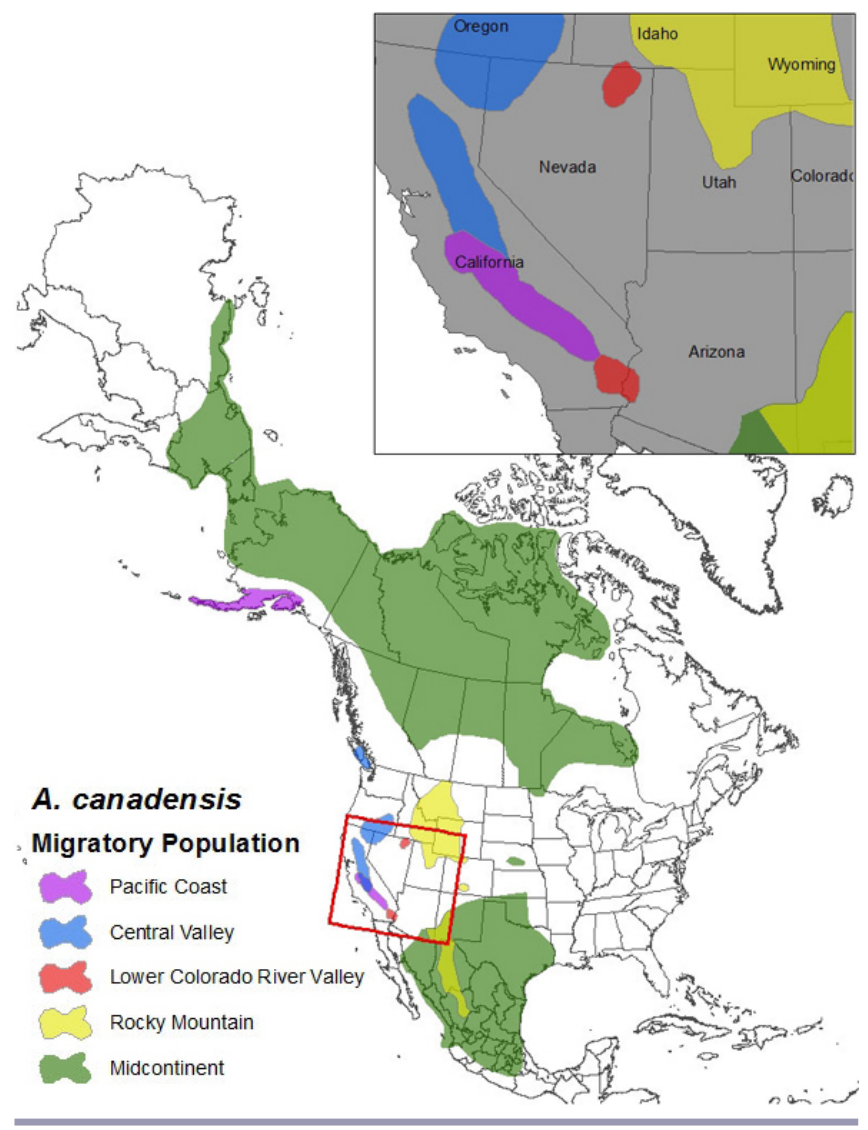

\section{Cibola and the Lower Colorado River Valley}

The Cibola National Wildlife Refuge (NWR) is 6729 ha and is located $69 \mathrm{~m}$ above sea level in the Colorado River floodplain, better known as the Lower Colorado River Valley (LCRV), and it is surrounded by Sonoran Desert ridges (Carver and Caudill 2007). Cibola NWR runs alongside $19.3 \mathrm{~km}$ of the Colorado River and contains $16 \mathrm{~km}$ of backwater from the Colorado River (U.S. Fish and Wildlife Service [USFWS] 2013b, 2017). The main land cover types of the refuge include agriculture, i.e., alfalfa (Medicago sativa), winter wheat (Triticum aestivum), and corn (Zea mays); the Lower Colorado River; moist-soil management units; salt cedar (Tamarix spp.) stands; cottonwood-willow stands (Populus fremontii, Salix exigua, and S. gooddingii); and desert shrub scrub (USFWS 2013a). Mean low and high temperatures for spring, summer, fall, and winter are $13-31^{\circ} \mathrm{C}, 23-41^{\circ} \mathrm{C}, 14-31^{\circ}$ $\mathrm{C}$, and $5-20^{\circ} \mathrm{C}$, respectively (U.S. Climate Data 2014). Yearly rainfall rarely exceeds $5.1 \mathrm{~cm}$, with the peak rainfall occurring December through February (USFWS 2013a, U.S. Climate Data 2014). Sandhill Cranes use Cibola NWR during winter along with the rest of the LCRV that has similar habitat, including alfalfa, corn, and winter wheat fields belonging to private owners or the Colorado River Indian Tribes.

\section{Sonny Bono Salton Sea and Imperial Valley}

The Sonny Bono Salton Sea NWR is 15,240 ha located in the Imperial Valley just south of the Salton Sea and $64 \mathrm{~km}$ north of the Mexico border (USFWS 2013b). Nearby cities include Calipatria to the east and Westmorland to the south. Despite being in the Sonoran Desert, the refuge receives water via agricultural runoff and irrigation from the Colorado River and serves as a consistent wintering ground for Sandhill Cranes (USFWS 2013b). Common habitat types found on the refuge include agricultural fields (alfalfa, wheat, rye grass [Lolium perenne], milo [Sorghumbicolor], millet [Pennisetum glaucum], and sudan grass [Sorghum $\times$ drummondii]), moist-soil management units, permanently flooded wetlands, and tree rows (USFWS 2013b).

The Imperial Valley is located in Imperial County in southeast California and stretches $80 \mathrm{~km}$ from the southern tip of the Salton Sea to the Mexican border (Eneva et al. 2012). Much of the area in the Imperial Valley is managed for agriculture. More than 100 different commodities are produced by farmers throughout the valley, many of which are valuable forage for cranes (Reinecke and Krapu 1986, Iverson et al. 1987, McIvor and Conover 1994, Imperial County Farm Bureau 2017). Abundant waste grain is available in the Imperial Valley fields and granaries (Iverson et al. 1985, 1987, Sudgen et al. 1988). The mean temperature in the Imperial Valley is $13^{\circ} \mathrm{C}$ in the winter and $32^{\circ} \mathrm{C}$ in the summer. Yearly rainfall in the Imperial Valley is $\sim 9 \mathrm{~cm}$, and the majority of the rain occurs in the winter and early spring (Johnson et al. 2009).

\section{Long Valley, Idaho}

Located in west-central Idaho approximately $100 \mathrm{~km}$ north of Boise, Idaho, Long Valley $\left(44.52^{\circ} \mathrm{N}, 116.05^{\circ} \mathrm{W}\right)$ follows alongside the Payette River. The river weaves through the broad, flat, glaciated valley dominated by agricultural grasslands and dense riparian stands of lodgepole pine (Pinus contorta), surrounded by mountain ranges on all sides consisting of ponderosa pine (Pinus ponderosa), grand fir (Abies grandis), and Douglas fir (Pseudotsuga menziesii; Van Daele and Van Daele 1982). Lake Cascade, Payette Lake, and Little Payette Lake are located in the area.

\section{Field methods}

\section{Capture}

We chose trapping locations based on previous crane use during the days leading up to capture efforts in early January 2014. We set up rocket nets in partially mowed corn fields after we identified trapping locations in Cibola NWR and a granary just south of Brawley, California, in the Imperial Valley. Typically, we fired rockets when $\sim 12$ cranes were within the capture target. We placed cranes in burlap sacks for processing to prevent capture myopathy. We banded each crane with a size-9 USGS-issued aluminum band on its right tibiotarsus and fit select adults with a global 
positioning system (GPS) satellite platform transmitter terminal, or PTT (Microwave Telemetry Inc. [MTI], Colombia, Maryland, USA; white alphanumeric code, X00-X19, on black background), on their left tibiotarsus with the antennae pointed toward their feet and solar panels forward. We identified adults using head plumage characteristics (Lewis 1979). We collected the following information for each capture: location, method, bird identification (ID) number, band ID, age (after hatch year/hatch year), and transmitter ID for selected adults. We only tagged the largest adult in each family unit in an effort to (1) achieve the relatively smallest excess-weight burden and (2) remotely follow only 1 crane in each group and avoid psuedoreplication. We did not attempt to identify sex of captured or tagged cranes, which requires collecting blood, because our objectives did not warrant it.

\section{Location data}

We programmed PTTs to collect 4 GPS locations each day (0000, 0700, 1000, and 1500 hours) and record latitude, longitude, speed, course, and altitude at each location. We downloaded GPS data weekly from the ARGOS website (https://argos-system. clsamerica.com/cwi/Logon.do) and parsed it into KML and text files using MTI GPS data parsing software. Locations that were lost or compromised because of drained batteries or used twodimensional fixes, no fix, or low voltage to collect data were removed from analyses. In-flight locations were removed from the AMU analyses to ensure cranes were on the ground at the time of the location fix. Altitude was recorded by the PTTs for every location, but the PTT we used rounded the altitude up or down to the nearest $10 \mathrm{~m}$ (e.g., 10, 20,30), which is the difference of being on the ground or in-flight in some scenarios. Speed, which is only recorded when the crane is in motion, was the parameter used to distinguish locations when a bird was in flight instead. Speeds $>10$ knots were considered to be in-flight and removed.

\section{Statistical and ArcGIS methods}

\section{Migratory corridors}

We used a Brownian bridge movement model(BBMM) to develop migratory pathways represented as probability of use/presence contours. We truncated our data sets to include only points between breeding and winter seasons (Horne et al. 2007, Sawyer et al. 2009, Nielson et al. 2013) to delineate migration corridors. One similar movement analysis is the dynamic Brownian bridge movement model (dBBMM), which for some objectives is more accurate for migratory species (Kranstauber et al. 2012). However, we ultimately used results from the "BBMM" package in the program R (Horne et al. 2007, Sawyer et al. 2009, Nielson et al. 2013; R version i3863.0.2, http://www.r-project.org) because $\mathrm{dBBMM}$ was not able to magnify migration corridors as a result of overwhelming nonmigration data, but BBMM used a simpler algorithm and was able to draw migration corridors by estimating the path taken between locations. We used all migratory locations (Appendix 1) from the initial trapping through the point of transmitter failure or the conclusion of the spring 2016 migration. We used known breeding grounds and wintering grounds for individual cranes from 2014 data and the ceasing of large (>60 $\mathrm{km}$ ) north and south movements to define the completion of spring and fall migrations, respectively. For each pathway, we calculated $50 \%, 75 \%, 95 \%$, and $99 \%$ BBMM confidence contours of each migration. After we calculated confidence contours in the program R, we exported each into shapefiles and imported them into ArcGIS 10.2 (hereafter GIS; Environmental Systems Research Institute 2014). We created migration path maps by overlaying the $99 \%$ confidence contours from all PTT-tagged cranes for fall and spring migrations, resulting in 2 main corridors, 1 for each season, respectively. We created 1 "major" corridor that included data from all individuals and all migrations, except the notable outliers, which we later defined as minor corridors, to represent a cumulative LCRVP migratory corridor by overlaying all $99 \%$ confidence contours.

\section{Areas of migratory use}

Once we mapped migratory pathways, we identified AMUs in ArcMap 10.2. Our data set lacked overall abundance of Sandhill Cranes at each area, as well as habitat information, and therefore did not fit specific definitions for "stopover" or "staging" (sensu Warnock 2010). Therefore, we created and used the umbrella phrase, "area of migratory use," or AMU, to include all areas where the PTT-tagged cranes stopped during migration, which we defined as the individualized $75 \%$ confidence contour produced by BBMM. We isolated the $75 \%$ confidence contours and at least 2 subsequently time stamped locations within $40 \mathrm{~km}$ of each other to identify AMUs for fall (2014 and 2015) and spring (2014, 2015, and 2016) migrations. We only identified AMUs within the $75 \%$ confidence contours because we judged any locations outside this region to be population outliers. Because of numerous locations being close (within $40 \mathrm{~km}$ ) to each other, we picked the central location within each cluster of locations $(\geq$ 2 locations) to represent each area and added a $40-\mathrm{km}$ buffer to each central location to represent an AMU, which was then labeled by a flagship locality within the AMU, i.e., Mojave National Preserve. We ranked AMUs based on the number of cranes that used each, with 1 being the AMU with the greatest number of cranes and 21 being the AMU with the least number of cranes. If AMUs had the same number of cranes, then we considered the number of migrations (spring $n=3$, fall $n=2$ ) that individuals used the area to break the tie. For AMUs that were still tied, we considered the number of total locations among all individuals within that AMU. If all previously described criteria did not rank individuals, they were considered tied. We ranked the AMUs to grade their relative importance.

\section{Migratory description statistics}

We estimated distances cranes traveled during migrations by measuring the distance in ArcMap between an individual's consecutive migratory locations used in the BBMM migration corridor analyses and compiling segment lengths. To assess migration duration, we calculated the number of days between the final location on a wintering or summer ground and the first location recorded at the corresponding terminus for each individual. Although we had multiple time stamps $(\leq 4)$ for each tagged crane on any given day, we rounded up to whole days because of the uncertainty of exact departure and arrival times caused by gaps between time stamps. We assessed the length of time (days and hours) spent at AMUs by subtracting an individual's first PTT time stamp recorded within the boundaries of a given AMU from the last time stamp recorded in that same AMU in a migration. Gaps between time stamps cause uncertainty in exact time, so time spent at AMUs is the minimum duration there. Mean values were calculated for distance traveled, 
duration of migration, and time spent at AMUs. Means were calculated for fall and spring migrations. Means for time spent at AMUs did not include time stamps for stays represented by only one location.

\section{RESULTS}

\section{Capture}

We attached PTTs to 16 adult cranes in January 2014, including 10 transmitters at Cibola NWR and 6 transmitters in the Imperial Valley. At the conclusion of summer 2014, we captured a single juvenile near Donnelly, Idaho, that survived through its first (fall) migration (Collins et al. 2016). An additional juvenile was trapped in July 2015 again near Donnelly, Idaho. Based on the migratory behavior and summering ecology of these juveniles, we included both in fall 2015 and spring 2016 LCRVP crane migratory corridor and AMU analyses. Location data for the entire project had about a $76 \%$ "success" rate, with about $24 \%$ of locations removed for analyses.

\section{Migration corridors}

We used location data from 9 individuals in 2014 and 9 individuals in 2015 to delineate the fall migration corridor ( $99 \%$ confidence interval [CI]) and 14, 10, and 11 individuals from 2014 to 2016, respectively, to develop spring migration corridors (99\% CI) for each year included in that interval. A generalized migration corridor was estimated based on combining fall and spring corridors (Fig. 2). Fall and spring migration corridors, with the exception of 2 tangents taken by 2 cranes, followed similar paths: a direct corridor between winter and breeding grounds that only varied among individuals by location of migration termini. The minor corridors, defined by simply being exhibited by a minority of the sample ( 1 individual used 2 minor corridors, another one used the third), were discovered through data from the Idaho juvenile trapped in summer 2015 and an adult crane captured at Cibola NWR, and both occurred during the fall 2015 migration. That adult crane had traveled another minor corridor during its spring 2015 migration, resulting in 3 minor corridors extending east into Utah. The major corridor for the remaining migrations was a direct north-south path between summering and wintering grounds, and the widest widths of each seasonal corridor were similar $($ fall $=151 \mathrm{~km}$, spring $=146 \mathrm{~km})$. From the farthest north boundaries to the farthest south boundaries, the fall and spring migration corridors were $1378 \mathrm{~km}$ and $1422 \mathrm{~km}$, respectively. Farthest distances differed among seasons because LCRVP cranes did not always winter or summer or initiate migration in the exact locations as they did in prior migrations.

\section{Areas of migratory use}

We identified 21 AMUs throughout the 5 migrations (Appendix 1; Fig. 2). The Wayne E. Kirch Wildlife Management Area (hereafter Kirch WMA) was ranked first with 12 individuals using it over the course of 5 migrations, with a total of 29.26 crane days. Twelve of 18 cranes stopped at Kirch WMA; however, each visit averaged only $\sim 2$ days. Pahranagat NWR was ranked second with 12 individuals over the course of 5 migrations and for a total of 12.33 crane days (Appendix 1). Truxton Wash, Joshua Tree Wilderness, Burro Creek, and Deep Creek tied for the last rank, 17, with only 1 individual using each in 1 migration for less than 1 crane day each (Appendix 1). Seven AMUs were only used during the spring migrations, and 5 different AMUs were only used in the fall migrations, all of which were used by $\leq 2$ cranes (Appendix 1). Five AMUs were also summer termini for cranes, including Ruby Lake NWR, Lund, Humboldt River, Bear River, and Duck Valley Indian Reservation (DVIR), based on location data from summer. AMUs that exclusively held stays $\leq 1$ day were Cibola NWR, Joshua Tree Wilderness Area, North LCRV, Mojave National Preserve, Lake Mohave, DVIR, Truxton Wash, Greater Vegas Area, Burro Creek, Deep Creek, and Sevier River. AMUs where some birds stayed longer than 1 day, but less than 1 week, included Pahranagat NWR, Kirch WMA, and Snake River. Stays greater than 1 week were almost exclusively in known breeding areas during all migrations, including Humboldt River, Ruby Lake, Lund, NV, and Bear River AMUs. Payette River AMU in Idaho also had stays greater than 1 week, as did Green River along the typical Rocky Mountain population migration corridor and Meadow Valley Wash, but by fewer cranes.

Fig. 2. Map of migration corridors for the Lower Colorado River Valley population (LCRVP) of Greater Sandhill Cranes (Antigone canadensis tabida) plus 4 observed outlying paths taken by 2 tracked individuals. Crane "Cibola 006" is shown in blue, and crane "Idaho 005 " in red. All 4 migratory trajectories were taken in 2015. Dashed lines represent spring migrations, and solid lines represent fall migrations. We include all areas of migratory use identified for the LCRVP. Numerals represent the number of different tracked individuals that visited the area at least once (for $\geq 10$ hours). DVIR, Duck Valley Indian Reservation; LCRV, Lower Colorado River Valley; NWR, National Wildlife Refuge; WMA, Wildlife Management Area.

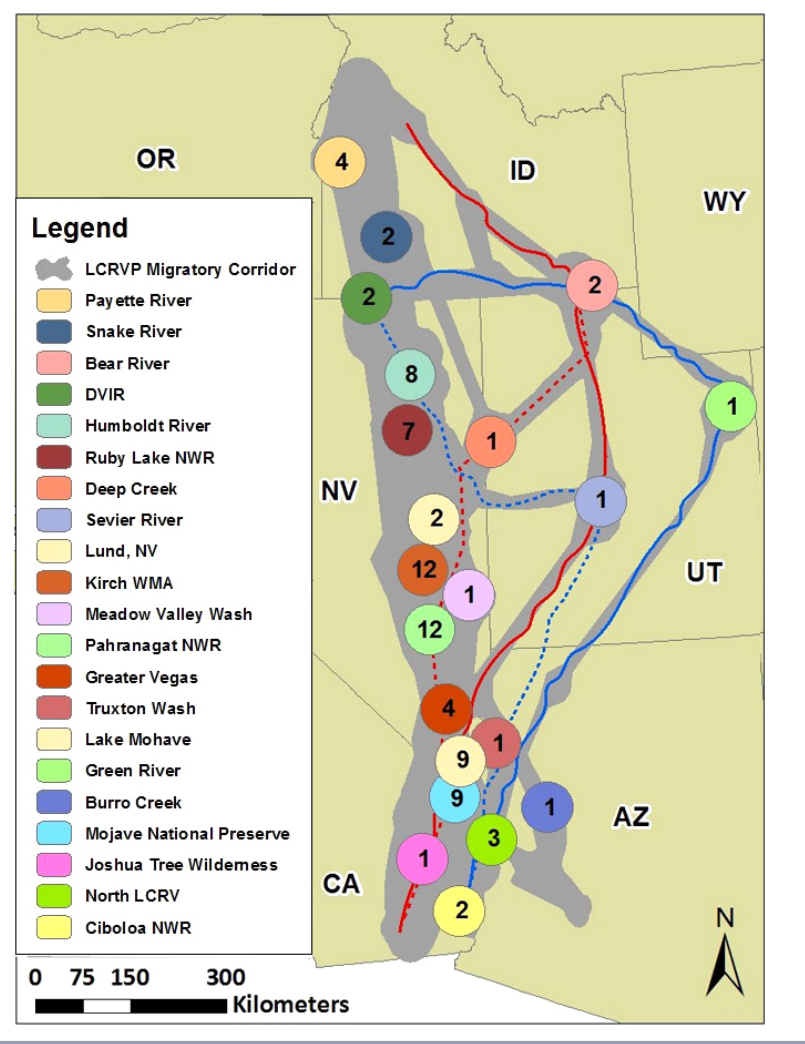




\section{Migratory descriptive statistics}

Average distance traveled across all tagged cranes and migrations was $951 \mathrm{~km}$ (minimum $=648$, maximum $=1544.36$, standard deviation $[\mathrm{SD}]=224.7$, median $=915.35$; Appendix 1). Average distance traveled during spring migration was shorter than fall migration distance average (spring $=935 \mathrm{~km}$, standard error [SE] $=31.36,95 \%$ CI $[873.96,996.89]$; fall $=979 \mathrm{~km}, \mathrm{SE}=58.27,95 \%$ CI [864.60, 1093.03]) but was not significantly shorter $(\mathrm{P}=0.48)$. The longest total distance traveled (path used, not necessarily a direct line) between winter and summer termini was $1544 \mathrm{~km}$, and the shortest was $648 \mathrm{~km}$ (Appendix 1). Average durations for seasonal migrations coincided with average distances recorded with a shorter spring migration average of 13.7 days and a fall migration average of 22.5 days (also not significantly different, $\mathrm{P}$ $=0.12$ ). Time spent at AMUs varied within migrations and between events (fall vs. spring). The average stay at an AMU during the spring migrations was 3.3 days $(n=74, \mathrm{SD}=5.85$, $95 \%$ CI $[1.92,4.63]$, median $=0.4)$. Average stay at an AMU during the fall migrations was 14.7 days $(n=25, \mathrm{SD}=19.46,95 \%$ CI [6.70, 22.77], median = 1.4). Durations at AMUs were significantly different $(\mathrm{P}=0.008)$ between seasons.

\section{DISCUSSION}

Variation in Sandhill Crane migration strategies across populations demonstrates the species' flexibility. Evolution arises from adaption; thus the predicted change in migration strategy, given resource availability, is likely to be expressed via changes in resource abundance across the various migration corridors. The characteristics of the LCRVP's migratory strategy best conform with the definition of a hop migration (Piersma 1987). MCP Sandhill Cranes exhibit a migration strategy between a skip and a jump, where MCP cranes leave winter grounds, stage on the Platte River in Nebraska, and either jump to the breeding grounds or hop to another staging area in Saskatchewan (Krapu et al. 2014). Fronczak et al. (2017) found that migration strategies of eastern population cranes vary but generally share definitive characteristics of a skip pattern. The individuals we tracked used 18 distinct AMUs along the $\sim 1000-\mathrm{km}$ major corridor and 3 additional AMUs along the minor corridors, with each crane making up to 6 and 4 recorded stops during spring and fall migrations, respectively. Typically, each crane spent a few days (3.3 days in spring and 14.7 days in fall; Appendix 1) at any one AMU, and migration duration varied widely among cranes (1-50 days in spring and 1-68 days in fall; Appendix 1).

Comprehensive research on migration resource availability or use has not been conducted on LCRVP cranes, despite concerns regarding the arid regions in their winter termini and along their migration corridor. AMUs consisted of both private agriculture (energy-rich row crops) and public WMAs (wetlands, some crops, and food plots) located within the boundaries of the Great Basin region. The Great Basin region contained several closed-system river and stream systems that typically had shallow, sandy, flat wetland habitats, often juxtaposed with agricultural regions (irrigation from nearby water bodies facilitates large agriculture operations in arid climates). The close proximity of necessary resources (food, drinking water, and roost sites) in the Great Basin region, and low population abundance, allowed the LCRVP to use it as its major corridor and also explains why Kirch WMA was the highest ranked AMU. LCRVP cranes roost and drink in shallow wetland systems and forage in nearby alfalfa fields or wheat plots during migration along their major corridor in Nevada (most of the major migratory corridor is in Nevada). Alfalfa, a cash crop in Nevada, and insects found on the crop have high crude protein, which could supplement fat reserves obtained during the winter. Kirch WMA, located in the White River Valley, has multiple reservoirs, wet meadows, and food plots planted in winter wheat (Nevada Department of Wildlife 2018). These resource attributes, supplemented with the alfalfa planted in the White River Valley, make Kirch WMA very attractive for Sandhill Cranes. We speculate that high accessibility, abundance, energy content, and digestibility of food, for which alfalfa, grain, and tuber residual habitats have high potential, paired with the fewer numbers of LCRV birds could facilitate shorter stays at AMUs during migration, because less time is needed to acquire a large amount of energy resources.

LCRVP cranes limit time along their spring migration corridor to gain a competitive advantage on the breeding grounds. There is evidence for breeding range expansion for the LCRVP, and our data indicated that dispersal of several individuals into new areas could be a consequence of limited nesting habitat available on the traditional breeding grounds (Conring 2016). Baker et al. (1995) found that Sandhill Crane pairs only select habitat within $200 \mathrm{~m}$ of their nest. They defend their resources and do not allow other cranes to forage or roost within their breeding home range (Lewis et al. 1977). Adult Sandhill Cranes also exhibit high nest site fidelity (Drewien 1973, August 2011), returning to the same summer home range year after year. This suggests that, at least during spring migration, competition for nesting and broodrearing territories on their breeding grounds may be the driver for the rapid migrations (13.7-day average spring migration [SD = 13.045]; Appendix 1) exhibited frequently. Krapu et al. (2014) suggested Arctic Circle snowmelt was one rationale for the long, rather slow (>3 months) spring migration of the MCP. Moreover, birds that breed at mid- to high latitudes time their arrival to summer grounds to avoid most, if not all, adverse weather and arrive when conditions are survivable (Carey 2009). The relatively lower latitudes for nesting in summer, compared with the MCP (Idaho and Nevada for LCRVP and Canada, Alaska, and Siberia for MCP), as well as lower elevation (within montane region) of nesting and brood-rearing habitats in summer, eliminate snowmelt as a major driver in AMU selection or other aspects of migratory ecology of the LCRVP in our study.

Resource availability along the migratory corridor is neither a limiting factor for the LCRVP nor the proximate reason cranes used multiple AMUs. The hop strategy, including the multiple stops at AMUs for short durations, may be driven by social behaviors. Stopping along a relatively short migration corridor provides opportunities for finding, establishing, or strengthening pair bonds. However, other populations require this same pair bonding, but not all exhibit the hop strategy. Sandhill Cranes are likely forging bonds opportunistically regardless of migratory strategy, either at many short-duration stops or at a few longduration staging sites. The mechanisms underpinning the LCRVP migratory hop strategy are not yet certain, but our results suggest social drivers and subadult dispersal as possible causes.

Some marked cranes followed minor (not direct north-south) migratory corridors, and some did not show site fidelity to termini 
every year (Conring 2016), supporting the possibility of dispersal via migrations. Dispersal and intermingling evidence for the Intermountain West populations is apparent (Collins et al. 2016). With the Rocky Mountain, LCRV, and Central Valley populations within close proximity to each other during summer, social mechanisms that result in dispersal of individuals, and subsequently genes, across the entirety of the Intermountain West are important for long-term conservation and highlight the importance of maintaining the AMUs for cranes in the western United States. LCRVP habitat use research on higher ranked AMUs could provide valuable information in regard to the specific resources that attract LCRVP cranes to those AMUs, which could serve as habitat management guidelines for the studied AMUs. By implementing researched habitat management efforts on all AMUs, not just the highly ranked ones, the apparent dispersal among the three Intermountain West populations of Sandhill Cranes would be better facilitated. The three western crane populations are currently regarded as distinct management entities, each having unique harvest guidelines and conservation statuses across states. As such, we highlight the importance of continuing comprehensive research on the extent of western Greater Sandhill Crane distributions to continue effectively assessing genetic diversity, impacts from harvest on discrete populations, and evaluation of conservation status across the distribution of the LCRV, Rocky Mountain, and Central Valley populations.

Responses to this article can be read online at: http://www.ace-eco.org/issues/responses.php/1352

\section{Acknowledgments:}

The Webless Migratory Game Bird Program within the U.S. Fish and Wildlife Service and Texas Tech University provided funds for the study. We thank the Cibola National Wildlife Refuge and the Sonny Bono Salton Sea National Wildlife Refuge staff and volunteers for providing housing during the field season and assisting in trapping efforts. John Vradenburg, Matt Boggie, Gary Ivey, Jeff Knetter, Steven Rimer, Stephanie Walden, Tom Anderson, and Brenda Zaun assisted in trapping efforts. Houston Safari Club supplied additional funds via scholarships. Ben Skipper and Laurie Groen provided assistance in teaching statistical analyses, and Cody Griffin assisted in ArcGIS efforts. We appreciate the reviews and comments provided by the subject editor and two reviewers to improve the quality of the manuscript. All trapping and handling protocols were approved by Texas Tech University Animal Care and Use Protocol \#13108-12.

\section{LITERATURE CITED}

Alerstam, T., A. Hedenström, and S. Åkesson. 2003. Longdistance migration: evolution and determinants. OIKOS 103:247-260. http://dx.doi.org/10.1034/j.1600-0706.2003.12559. $\mathrm{x}$

August, C. W. 2011. Reproductive ecology of greater Sandhill Cranes in Nevada. Thesis. University of Nevada, Reno, Nevada, USA.
Baker, B. W., B. S. Cade, W. L. Mangus, and J. L. McMillen. 1995. Spatial analysis of sandhill crane nesting habitat. Journal of Wildlife Management 59:752-758. http://dx.doi.org/10.2307/3801952

Carey, C. 2009. The impacts of climate change on the annual cycles of birds. Philosophical Transactions of the Royal Society B: Biological Sciences 364:3321-3330. http://dx.doi.org/10.1098/ rstb.2009.0182

Carver, E., and J. Caudill. 2007. Banking on nature 2006: the economic benefits to local communities of national wildlife refuge visitation. U.S. Fish and Wildlife Service, Washington, D.C., USA.

Collins, D. P., B. A. Grisham, C. M. Conring, J. M. Knetter, W. C. Conway, S. A. Carleton, and M. A. Boggie. 2016. New summer areas and mixing of two greater sandhill crane populations in the Intermountain West. Journal of Fish and Wildlife Management 7:141-152. http://dx.doi.org/10.3996/042015-JFWM-036

Conring, C. M. 2016. Spatial ecology of the Lower Colorado River Valley population of greater sandhill cranes. Thesis. Texas Tech University, Lubbock, Texas, USA.

Drewien, R. C. 1973. Ecology of Rocky Mountain greater sandhill cranes. Dissertation. University of Idaho, Moscow, Idaho, USA.

Dubovsky, J. A. 2018. Status and harvests of sandhill cranes: midcontinent, Rocky Mountain, Lower Colorado River Valley and eastern populations. Administrative Report, U.S. Fish and Wildlife Service, Lakewood, Colorado, USA.

Eneva, M., D. Adams, G. Falorni, and J. Morgan. 2012. Surface deformation in Imperial Valley, CA, from satellite radar interferometry. Geothermal Resources Council Transactions 36:1339-1344.

Environmental Systems Research Institute (ESRI). 2014. ArcGIS Desktop: Release 10. ESRI, Redlands, California, USA.

Fronczak, D. L. 2014. Distribution, migration chronology, and survival rates of eastern population sandhill cranes. Thesis. University of Minnesota, Minneapolis, Minnesota, USA.

Fronczak, D. L., D. E. Andersen, E. E. Hanna, and T. R. Cooper. 2017. Distribution and migration chronology of eastern population Sandhill Cranes. Journal of Wildlife Management 81:1021-1032. http://dx.doi.org/10.1002/jwmg.21272

Galván, I. 2005. Migration strategies of the Great Cormorant wintering inland in Spain. Waterbirds 28:301-307. http://dx.doi. org/10.1675/1524-4695(2005)028[0301:MSOTGC]2.0.CO;2

Holmgren, N., H. Ellegren, and J. Pettersson. 1993. Stopover length, body mass, and fuel deposition rate in autumn migrating adult Dunlins Calidris alpina: evaluating the effects of molting status and age. ARDEA 81:9-20.

Horne, J. S., E. O. Garton, S. M. Krone, and J. S. Lewis. 2007. Analyzing animal movements using Brownian bridges. Ecology 88:2354-2363. http://dx.doi.org/10.1890/06-0957.1

Imperial County Farm Bureau. 2017. Imperial Valley agriculture. Imperial County Farm Bureau, El Centro, California, USA. [online] URL: https://www.icfb.net/i-v-agriculture 
Iverson, G. C., P. A. Vohs, and T. C. Tacha. 1985. Habitat use by sandhill cranes wintering in western Texas. Journal of Wildlife Management 49:1074-1083. http://dx.doi.org/10.2307/3801398

Iverson, G. C., P. A. Vohs, and T. C. Tacha. 1987. Habitat use by mid-continent sandhill cranes during spring migration. Journal of Wildlife Management 51:448-458. http://dx.doi. org/10.2307/3801033

Ivey, G. L., C. P. Herziger, and T. J. Hoffmann. 2005. Annual movements of Pacific coast sandhill cranes. Pages 25-36 in F. Chavez-Ramirez, editor. Proceedings of the Ninth North American Crane Workshop, Jan 17-20, 2003. North American Crane Working Group, Sacramento, California, USA.

Johnson, P. I., R. M. Gersberg, M. Rigby, and S. Roy. 2009. The fate of selenium in the Imperial and Brawley constructed wetlands in the Imperial Valley (California). Ecological Engineering 35:908-913. http://dx.doi.org/10.1016/j.ecoleng.2008.12.020

Kranstauber, B., R. Kays, S. D. LaPoint, M. Wikelski, and K. Safi. 2012. A dynamic Brownian bridge movement model to estimate utilization distributions for heterogeneous animal movement. Journal of Animal Ecology 81:738-746. http://dx.doi. org/10.1111/j.1365-2656.2012.01955.x

Krapu, G. L., D. A. Brandt, P. J. Kinzel, and A. T. Pearse. 2014. Spring migration ecology of the mid-continent sandhill crane population with an emphasis on use of the Central Platte River Valley, Nebraska. Wildlife Monographs 189:1-41. http://dx.doi. org/10.1002/wmon.1013

Krapu, G. L., D. E. Facey, E. K. Fritzell, and D. H. Johnson. 1984. Habitat use by migrant sandhill cranes in Nebraska. Journal of Wildlife Management 48:407-417. http://dx.doi. org/10.2307/3801172

Lewis, J. C. 1979. Field identifications of juvenile sandhill cranes. Journal of Wildlife Management 43:211-214. http://dx.doi. org/10.2307/3800655

Lewis, J. C., G. W. Archibald, R. C. Drewien, C. R. Frith, E. A. Gluesing, R. D. Klataske, C. D. Littlefield, J. Sands, W. J. D. Stephen, and L. E. Williams. 1977. Sandhill Crane (Grus canadensis). Pages 5-43 in G. C. Sanderson, editor. Management of migratory and upland game birds in North America. International Association of Fish and Wildlife Agencies, Washington, D.C., USA.

Lovvorn, J. R., and C. M. Kirkpatrick. 1981. Roosting behavior and habitat of migrant greater sandhill cranes. Journal of Wildlife Management 45:842-857. http://dx.doi.org/10.2307/3808093

McIvor, D. E., and M. R. Conover. 1994. Habitat preference and diurnal use among Greater Sandhill Cranes. Great Basin Naturalist 54:329-334.

Nevada Department of Wildlife(NDOW). 2018. Wayne E. Kirch Wildlife Management Area. NDOW, Reno, Nevada, USA. [online] URL: http://www.ndow.org/uploadedFiles/ndoworg/ Content/public_documents/Nevada_Wildlife/wma_kirch.pdf
Nielson, R. M., H. Sawyer, and T. L. McDonald. 2013. Package 'BBMM' manual. R Foundation for Statistical Computing, Vienna, Austria. [online] URL: https://cran.r-project.org/web/ packages/BBMM/BBMM.pdf

Petrula, M. J., and T. C. Rothe. 2005. Migration chronology, routes, and distribution of Pacific Flyway population lesser sandhill cranes. Pages 53-68 in F. Chavez-Ramirez, editor. Proceedings of the Ninth North American Crane Workshop, Jan 17-20, 2003. North American Crane Working Group, Sacramento, California, USA.

Piersma, T. 1987. Hop, skip, or jump? Constraints on migration of arctic waders by feeding, fattening, and flight speed [title translated from the Dutch]. Limosa 60:185-194.

Reinecke, K. J., and G. L. Krapu. 1986. Feeding ecology of sandhill cranes during spring migration in Nebraska. Journal of Wildlife Management 50:71-79. http://dx.doi.org/10.2307/3801490

Restani, M. 2000. Age-specific stopover behavior of migrant Bald Eagles. Wilson Journal of Ornithology 112:28-34. http://dx. doi.org/10.1676/0043-5643(2000)112[0028:ASSBOM]2.0.CO;2

Sawyer, H., J. M. Kauffman, R. M. Nielson, and J. S. Horne. 2009. Identifying and prioritizing ungulate migration routes for landscape-level conservation. Ecological Applications 19:2016-2025. http://dx.doi.org/10.1890/08-2034.1

Sudgen, L. G., R. G. Clark, E. J. Woodsworth, and H. Greenwood. 1988. Use of cereal fields by foraging sandhill cranes in Saskatchewan. Journal of Applied Ecology 25:111-124. http://dx.doi.org/10.2307/2403613

Tacha, T. C. 1988. Social organization of Sandhill Cranes from midcontinental North America. Wildlife Monographs 99:3-37.

U.S. Climate Data. 2014. Climate Blythe - California. U.S. Climate Data, Washington, D.C., USA. [online] URL: http:// www.usclimatedata.com/climate/blythe/california/united-states/ usca0110

U.S. Fish and Wildlife Service (USFWS). 2013a. All about Cibola National Wildlife Refuge. USFWS, Cibola, Arizona, USA. [online] URL: http://www.fws.gov/refuge/Cibola/about.html

U.S. Fish and Wildlife Service (USFWS). 2013b. Cibola National Wildlife Refuge. USFWS, Cibola, Arizona, USA. [online] URL: https://www.fws.gov/refuges/profiles/index.cfm?id=22540

U.S. Fish and Wildlife Service (USFWS). 2017. Birds of Cibola National Wildlife Refuge. USFWS, Cibola, Arizona, USA. [online] URL: https://www.fws.gov/uploadedFiles/Cibola $\%$ 20Birds $\% 20$ Fact $\% 20$ Sheet $\% 202017$.pdf

Van Daele, L. J., and H. A. Van Daele. 1982. Factors affecting the productivity of Ospreys nesting in west-central Idaho. Condor 84:292-299. http://dx.doi.org/10.2307/1367371

Warnock, N. 2010. Stopping vs. staging: the difference between a hop and a jump. Journal of Avian Biology 41:621-626. http:// dx.doi.org/10.1111/j.1600-048X.2010.05155.x 
Winkler, D. W., C. Jørgensen, C. Both, A. I. Houston, J. M. McNamara, D. J. Levey, J. Partecke, A. Fudickar, A. Kacelnik, D. Roshier, and T. Piersma. 2014. Cues, strategies, and outcomes: how migrating vertebrates track environmental change. Movement Ecology 2:10. http://dx.doi.org/10.1186/2051-3933-2-10 
Appendix 1. Supplementary summary statistics tables. 
Table A1.1. Areas of migratory use identified for the Lower Colorado River Valley Population of Sandhill Cranes (Antigone canadensis tabida) during all five migrations between spring 2014 and spring 2016. *Areas of Migratory Use located along the minor corridors.

\begin{tabular}{|c|c|c|c|c|c|c|c|c|c|c|c|}
\hline \multirow[b]{2}{*}{$\begin{array}{l}\text { Rank } \\
\text { ing }\end{array}$} & \multirow[b]{2}{*}{$\begin{array}{c}\text { Area of } \\
\text { Migratory Use }\end{array}$} & \multicolumn{5}{|c|}{ Spring } & \multicolumn{3}{|c|}{ Fall } & \multicolumn{2}{|c|}{ Both Seasons } \\
\hline & & $\begin{array}{l}\text { Sum of } \\
\text { Days }\end{array}$ & $\begin{array}{l}\text { Migrat } \\
\text { ions }\end{array}$ & $\begin{array}{c}\text { Cranes (18 } \\
\operatorname{max)}\end{array}$ & $\begin{array}{c}\text { Years (3 } \\
\max )\end{array}$ & $\begin{array}{c}\text { Sum of } \\
\text { Days }\end{array}$ & $\begin{array}{c}\text { Migrat } \\
\text { ions }\end{array}$ & $\begin{array}{c}\text { Cranes (18 } \\
\operatorname{max)}\end{array}$ & $\begin{array}{c}\text { Years (2 } \\
\max )\end{array}$ & $\begin{array}{c}\text { Sum of } \\
\text { Days }\end{array}$ & $\begin{array}{l}\text { Ave Duration } \\
\text { (days) }\end{array}$ \\
\hline 1 & Kirch WMA & 20.47 & 13 & 10 & 3 & 8.79 & 2 & 2 & 1 & 29.26 & 1.95 \\
\hline 2 & $\begin{array}{c}\text { Pahranagat } \\
\text { NWR }\end{array}$ & 5.54 & 10 & 7 & 2 & 6.79 & 2 & 2 & 1 & 12.33 & 1.03 \\
\hline 3 & Mojave NP & 3.1 & 8 & 7 & 3 & 0.42 & 2 & 2 & 2 & 3.51 & 0.35 \\
\hline 4 & Lake Mohave & 2.79 & 7 & 6 & 3 & 0.58 & 2 & 2 & 1 & 3.38 & 0.38 \\
\hline 5 & $\begin{array}{l}\text { Humboldt } \\
\text { River }\end{array}$ & 98.25 & 11 & 5 & 3 & 118.58 & 4 & 4 & 1 & 216.83 & 14.46 \\
\hline 6 & $\begin{array}{l}\text { Ruby Lake } \\
\text { NWR }\end{array}$ & 33.08 & 7 & 5 & 3 & 6.79 & 1 & 1 & 1 & 39.87 & 4.98 \\
\hline 7 & Payette River & 29.63 & 4 & 4 & 3 & 143.54 & 3 & 3 & 2 & 173.17 & 24.74 \\
\hline 8 & $\begin{array}{c}\text { Greater Vegas } \\
\text { Area }\end{array}$ & 1.08 & 3 & 3 & 2 & 0.71 & 2 & 2 & 1 & 1.79 & 0.36 \\
\hline 9 & North LCRV & 0.42 & 1 & 1 & 1 & 0 & 0 & 0 & 0 & 0.42 & 0.42 \\
\hline 10 & Cibola NWR & 0 & 0 & 0 & 0 & 0.54 & 2 & 2 & 2 & 0.54 & 0.27 \\
\hline 11 & Lund NV & 9.84 & 2 & 2 & 2 & 0 & 0 & 0 & 0 & 9.84 & 4.92 \\
\hline 12 & Snake River & 2.05 & 2 & 2 & 2 & 0 & 0 & 0 & 0 & 2.05 & 1.02 \\
\hline
\end{tabular}




$\begin{array}{cccccccccccc}13 & \text { Bear River* } & 0 & 0 & 0 & 0 & 58.5 & 2 & 2 & 1 & 58.5 & 29.25 \\ 14 & \text { DVIR } & 0.79 & 2 & 2 & 1 & 0 & 0 & 0 & 0 & 0.79 & 0.4 \\ 15 & \text { Green River* } & 0 & 0 & 0 & 0 & 25.42 & 1 & 1 & 1 & 25.42 & 25.42 \\ & \text { Meadow } & & & & & & & & & \\ 16 & \text { Valley Wash } & 7.42 & 1 & 1 & 2 & 0 & 0 & 0 & 0 & 7.42 & 7.42 \\ 16 & \text { Sevier River* } & 0 & 0 & 0 & 0 & 8 & 1 & 1 & 1 & 8 \\ 17 & \text { Joshua Tree } & 0 & 0 & 0 & 0 & 0.29 & 1 & 1 & 1 & 0.29 & 0.29 \\ 17 & \text { Truxton Wash } & 0.13 & 1 & 1 & 1 & 0 & 0 & 0 & 0 & 0.13 & 0.13 \\ 17 & \text { Burro Creek } & 0.42 & 1 & 1 & 1 & 0 & 0 & 0 & 0 & 0.42 & 0.42 \\ 17 & \text { Deep Creek } & 0.42 & 1 & 1 & 1 & 0 & 0 & 0 & 0 & 0.42 & 0.42\end{array}$


Table A1.2. Average Time Spent (Days) by Greater Sandhill Cranes (Antigone canadensis tabida) at Areas of Migratory Use (AMU) from Spring 2014-Spring 2016. *NA indicates the site had no recorded visits

$\geq 3$ hours during that migration and were not included in averages.

Area of Migratory Use

Spring

Fall

$\begin{array}{lcccccc} & X & \sigma_{\bar{x}} & n & X & \sigma_{\bar{x}} & n \\ \text { Cibola NWR } & \text { NA } & \text { NA } & \text { NA } & 0.27 & 0.15 & 2 \\ \text { Joshua Tree } & \text { NA } & \text { NA } & \text { NA } & 0.29 & 0 & 1 \\ \text { North LCRV } & 0.42 & 0 & 1 & \text { NA } & \text { NA } & \text { NA } \\ \text { Mojave NP } & 0.39 & 0.02 & 8 & 0.21 & 0.08 & 2 \\ \text { Lake Mohave } & 0.4 & 0.05 & 7 & 0.29 & 0 & 2 \\ \text { Truxton Wash } & 0.13 & 0 & 1 & \text { NA } & \text { NA } & \text { NA } \\ \text { Greater Vegas Area } & 0.36 & 0.04 & 3 & 0.35 & 0.06 & 2 \\ \text { Pahranagat NWR } & 0.55 & 0.15 & 10 & 3.4 & 2.98 & 2 \\ \text { Meadow Valley Wash } & 7.42 & 0 & 1 & \text { NA } & \text { NA } & \text { NA } \\ \text { Kirch WMA } & 1.57 & 0.41 & 13 & 2.96 & 2.83 & 2 \\ \text { Lund NV } & 4.92 & 4.5 & 2 & \text { NA } & \text { NA } & \text { NA } \\ \text { Sevier River } & \text { NA } & \text { NA } & \text { NA } & 0.33 & 0 & 1 \\ \text { Ruby Lake NWR } & 4.71 & 2.86 & 7 & 6.79 & 0 & 1 \\ \text { Green River } & \text { NA } & \text { NA } & \text { NA } & 25.42 & 0 & 1 \\ \text { Humboldt River } & 11.39 & 2.54 & 11 & 29.65 & 9.9 & 4 \\ \text { DVIR } & 0.4 & 0.02 & 2 & \text { NA } & \text { NA } & \text { NA } \\ \text { Bear River } & \text { NA } & \text { NA } & \text { NA } & 29.25 & 6.5 & 2 \\ \text { Snake River } & 1.02 & 0.6 & 2 & \text { NA } & \text { NA } & \text { NA } \\ \text { Payette River } & 7.41 & 4.26 & 4 & 47.85 & 8.1 & 3 \\ \text { Burro Creek } & 0.42 & 0 & 1 & \text { NA } & \text { NA } & \text { NA } \\ \text { Deep Creek } & 0.42 & 0 & 1 & \text { NA } & \text { NA } & \text { NA } \\ \text { All AMIs } & 3.27 & 0.68 & 74 & 14.74 & 3.89 & 25\end{array}$


Table A1.3. Migration routes used by satellite-tagged greater Sandhill Cranes (Antigone canadensis tabida) of the Lower Colorado River Valley Population.

\begin{tabular}{lcccccc} 
& Capture & Spring & \multicolumn{3}{c}{ Spring } & Spring \\
Crane ID & Date & 2014 & Fall 2014 & 2015 & Fall 2015 & 2016 \\
CIB001 & $1 / 1 / 2014$ & Major & Major & Unknown & Unknown & Major \\
CIB002 & $1 / 9 / 2014$ & Major & Major & Major & Major & Major \\
CIB003 & $1 / 9 / 2014$ & Major & Major & Major & Unknown & Major \\
CIB004 & $1 / 9 / 2014$ & Major & Unknown & Unknown & Unknown & Unknown \\
CIB005 & $1 / 9 / 2014$ & Major & Major & Major & Unknown & Major \\
CIB006 & $1 / 9 / 2014$ & Major & Major & Minor & Minor & Major \\
CIB007 & $1 / 14 / 2014$ & Major & Major & Unknown & Unknown & Unknown \\
CIB008 & $1 / 14 / 2014$ & Major & Major & Major & Major & Major \\
CIB009 & $1 / 14 / 2014$ & Major & Unknown & Unknown & Unknown & Unknown \\
CIB010 & $1 / 14 / 2014$ & Major & Unknown & Major & Unknown & Major \\
IV001 & $1 / 16 / 2014$ & Major & Major & Major & Major & Unknown \\
IV002 & $1 / 16 / 2014$ & Major & Major & Unknown & Unknown & Unknown \\
IV003 & $1 / 16 / 2014$ & Major & Major & Major & Major & Major \\
IV005 & $1 / 16 / 2014$ & Major & Major & Unknown & Major & Unknown \\
IV006 & $1 / 16 / 2014$ & Major & Major & Major & Major & Major \\
IV007 & $1 / 23 / 2014$ & Unknown & Major & Major & Major & Unknown \\
ID001 & $7 / 29 / 2014$ & & Unknown & Unknown & Major & Major \\
ID005 & $7 / 30 / 2015$ & & & & Minor & Minor
\end{tabular}


Table A1.4. Migration start and end dates, lengths (days), and distances (km) for our sample of satellite- tagged greater Sandhill Cranes (Antigone canadensis tabida) of the Lower Colorado Valley Population for fall migration.

\begin{tabular}{|c|c|c|c|c|c|}
\hline Bird ID & Start & Arrival & Length (days) & Distance $(\mathrm{km})$ & Fall \\
\hline CIB001 & 8-Sep-14 & 14-Nov-14 & 67 & $1,310.06$ & 2014 \\
\hline CIB002 & 27-Aug-14 & 14-Oct-14 & 48 & 858.51 & 2014 \\
\hline CIB003 & 31-Aug-14 & 3-Oct-14 & 33 & 988.64 & 2014 \\
\hline CIB004 & 29-Sep-14 & 3-Oct-14 & 4 & 990.43 & 2014 \\
\hline CIB005 & 1-Oct-14 & 2-Oct-14 & 1 & 780.5 & 2014 \\
\hline CIB006 & 30-Sep-14 & 3-Oct-14 & 3 & 987.81 & 2014 \\
\hline CIB008 & 31-Aug-14 & 14-Oct-14 & 44 & 804.83 & 2014 \\
\hline CIB010 & 30-Sep-14 & 2-Oct-14 & 2 & 774.04 & 2014 \\
\hline IV001 & 30-Sep-14 & 2-Oct-14 & 2 & 737.76 & 2014 \\
\hline IV003 & 29-Sep-14 & 2-Oct-14 & 3 & 681.22 & 2014 \\
\hline IV005 & 1-Oct-14 & 5-Oct-14 & 4 & $1,005.39$ & 2014 \\
\hline IV006 & 30-Sep-14 & 3-Oct-14 & 3 & 917.33 & 2014 \\
\hline CIB002 & $11-O c t-15$ & $23-$ Oct-15 & 12 & 786.85 & 2015 \\
\hline CIB006 & 16-Sep-15 & 8-Nov-15 & 53 & $1,544.36$ & 2015 \\
\hline CIB008 & 8-Oct-15 & $10-O c t-15$ & 2 & 851.97 & 2015 \\
\hline CIB010 & 3-Oct-15 & 7-Oct-15 & 4 & 842.87 & 2015 \\
\hline IV001 & 7-Sep-15 & 21-Sep-15 & 14 & 748.33 & 2015 \\
\hline IV003 & 2-Oct-15 & 3-Oct-15 & 1 & 721.67 & 2015 \\
\hline IV006 & 10-Sep-15 & 14-Oct-15 & 34 & 876.61 & 2015 \\
\hline IV007 & 17-Aug-15 & 24-Oct-15 & 68 & $1,433.50$ & 2015 \\
\hline ID001 & 27-Sep-15 & 9-Nov-15 & 43 & $1,350.16$ & 2015 \\
\hline ID005 & 3-Sep-15 & 23-Oct-15 & 50 & $1,541.01$ & 2015 \\
\hline Average & & & 22.5 & 978.81 & \\
\hline Min & & & 1 & 681.22 & \\
\hline Max & & & 68 & 1544.36 & \\
\hline Median & $10 / 1 / 2014$ & $10 / 29 / 2014$ & 8 & 867.56 & \\
\hline SD (sample) & & & 23.95 & 273.33 & \\
\hline $95 \%$ CI & & & & & \\
\hline Upper & & & & 864.06 & \\
\hline $95 \% \mathrm{CI}$ & & & & & \\
\hline Lower & & & & 1093.03 & \\
\hline
\end{tabular}


Table A1.5. Migration start and end dates, length of stay (days), and distances (km) for our sample of satellite-tagged greater Sandhill Cranes (Antigone canadensis tabida) of the Lower Colorado Valley Population for spring migration.

\begin{tabular}{|c|c|c|c|c|c|}
\hline Bird ID & Start & Arrival & Length (days) & Distance $(\mathrm{km})$ & Spring \\
\hline CIB001 & 10-Mar-14 & 30-Mar-14 & 20 & $1,251.63$ & 2014 \\
\hline CIB002 & 26-Feb-14 & 2-Mar-14 & 4 & 850.91 & 2014 \\
\hline CIB003 & 26-Feb-14 & 20-Mar-14 & 22 & 954.38 & 2014 \\
\hline CIB004 & 26-Feb-14 & 23-Mar-14 & 25 & 940.08 & 2014 \\
\hline CIB005 & 9-Mar-14 & 13-Mar-14 & 4 & 803.66 & 2014 \\
\hline CIB006 & 26-Feb-14 & 23-Mar-14 & 25 & 987.59 & 2014 \\
\hline CIB007 & 26-Feb-14 & 23-Mar-14 & 25 & 994.16 & 2014 \\
\hline CIB008 & 9-Mar-14 & 14-Mar-14 & 5 & 928.21 & 2014 \\
\hline CIB009 & 26-Feb-14 & 7-Mar-14 & 9 & $1,255.92$ & 2014 \\
\hline CIB010 & 26-Feb-14 & 3-Mar-14 & 5 & 842.51 & 2014 \\
\hline IV001 & 23-Feb-14 & 26-Feb-14 & 3 & 664.84 & 2014 \\
\hline IV003 & 22-Feb-14 & 24-Feb-14 & 2 & 659.81 & 2014 \\
\hline IV005 & 23-Feb-14 & 26-Feb-14 & 3 & $1,009.45$ & 2014 \\
\hline IV006 & 27-Feb-14 & 6-Mar-14 & 7 & 913.37 & 2014 \\
\hline CIB002 & 28-Feb-15 & 2-Mar-15 & 2 & 864.84 & 2015 \\
\hline CIB003 & 22-Feb-15 & 13-Mar-15 & 19 & 987.4 & 2015 \\
\hline CIB004 & 12-Feb-15 & 27-Mar-15 & 43 & 976.28 & 2015 \\
\hline CIB005 & 8-Mar-15 & 11-Mar-15 & 3 & 777.25 & 2015 \\
\hline CIB006 & 22-Feb-15 & 19-Mar-15 & 25 & $1,014.90$ & 2015 \\
\hline CIB008 & 7-Mar-15 & 13-Mar-15 & 6 & 931.8 & 2015 \\
\hline CIB010 & 26-Feb-15 & 3-Mar-15 & 5 & 840.9 & 2015 \\
\hline IV001 & $25-F e b-15$ & 6-Mar-15 & 9 & 716.63 & 2015 \\
\hline IV003 & 17-Feb-15 & 19-Feb-15 & 2 & 671.19 & 2015 \\
\hline IV006 & 26-Feb-15 & 11-Mar-15 & 13 & 847.6 & 2015 \\
\hline IV007 & $15-F e b-15$ & 16-Mar-15 & 29 & $1,319.15$ & 2015 \\
\hline CIB001 & 9-Feb-16 & 30-Mar-16 & 50 & 1340.66 & 2016 \\
\hline CIB002 & 29-Feb-16 & 3-Mar-16 & 3 & 879 & 2016 \\
\hline CIB003 & 2-Feb-16 & 12-Mar-16 & 39 & 945 & 2016 \\
\hline CIB004 & 25-Feb-16 & 30-Mar-16 & 34 & 971 & 2016 \\
\hline CIB005 & 8-Mar-15 & 11-Mar-15 & 3 & 794 & 2016 \\
\hline CIB006 & $25-F e b-16$ & 20-Mar-16 & 24 & 1051 & 2016 \\
\hline CIB008 & 2-Mar-16 & 16-Mar-16 & 14 & 950 & 2016 \\
\hline CIB010 & $25-F e b-16$ & 28-Feb-16 & 3 & 781 & 2016 \\
\hline ID001 & 1-Mar-16 & 20-Mar-16 & 19 & 1442.20 & 2016 \\
\hline ID005 & 29-Feb-16 & 5-Mar-16 & 5 & 1156 & 2016 \\
\hline IV001 & 23-Feb-16 & 29-Feb-16 & 6 & 731 & 2016 \\
\hline IV003 & 17-Feb-16 & 18 -Feb-16 & 1 & 648 & 2016 \\
\hline IV006 & 1-Mar-16 & 5-Mar-16 & 4 & 853 & 2016 \\
\hline Average & & & 13.68 & 935.43 & \\
\hline Min & & & 1 & 648 & \\
\hline Max & & & 50 & 1442.20 & \\
\hline Median & 23-Feb-15 & 11-Mar-15 & 6.5 & 930.005 & \\
\hline SD (sample) & & & 13.045 & 193.315 & \\
\hline $95 \%$ CI Upper & & & & 873.96 & \\
\hline 95\% CI Lower & & & & 996.89 & \\
\hline
\end{tabular}


